\title{
First approaches towards modelling glacial hazards in the Mount Cook region of New Zealand's Southern Alps
}

\author{
S. K. Allen ${ }^{1}$, D. Schneider ${ }^{2,3}$, and I. F. Owens ${ }^{1}$ \\ ${ }^{1}$ Department of Geography, University of Canterbury, Christchurch, 8140, New Zealand \\ ${ }^{2}$ Glaciology, Geomorphodynamics and Geochronology, Dept. of Geography, University of Zurich-Irchel, 8057, Switzerland \\ ${ }^{3}$ WSL Institute for Snow and Avalanche Research, SLF, Davos Dorf, 7250, Switzerland
}

Received: 11 September 2008 - Revised: 15 December 2008 - Accepted: 24 March 2009 - Published: 31 March 2009

\begin{abstract}
Flood and mass movements originating from glacial environments are particularly devastating in populated mountain regions of the world, but in the remote Mount Cook region of New Zealand's Southern Alps minimal attention has been given to these processes. Glacial environments are characterized by high mass turnover and combined with changing climatic conditions, potential problems and process interactions can evolve rapidly. Remote sensing based terrain mapping, geographic information systems and flow path modelling are integrated here to explore the extent of ice avalanche, debris flow and lake flood hazard potential in the Mount Cook region. Numerous proglacial lakes have formed during recent decades, but well vegetated, low gradient outlet areas suggest catastrophic dam failure and flooding is unlikely. However, potential impacts from incoming mass movements of ice, debris or rock could lead to dam overtopping, particularly where lakes are forming directly beneath steep slopes. Physically based numerical modeling with RAMMS was introduced for local scale analyses of rock avalanche events, and was shown to be a useful tool for establishing accurate flow path dynamics and estimating potential event magnitudes. Potential debris flows originating from steep moraine and talus slopes can reach road and built infrastructure when worst-case runout distances are considered, while potential effects from ice avalanches are limited to walking tracks and alpine huts located in close proximity to initiation zones of steep ice. Further local scale studies of these processes are required, leading towards a full hazard assessment, and changing glacial conditions over coming decades will necessitate ongoing monitoring and reassessment of initiation zones and potential impacts.
\end{abstract}

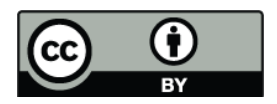

Correspondence to: S. K. Allen (simon.allen@pg.canterbury.ac.nz)

\section{Introduction}

Glacial hazards have been defined as any glacial or glacierrelated feature or process that adversely affect human activities (Reynolds, 1992). These hazards are a concern for many high mountain regions of the world and can have severe resource management implications relating to water availability and hydro-power generation (Reynolds, 1992; Richardson and Reynolds, 2000). Glaciers are highly sensitive to climate forcing, and in many regions glacial retreat during the past century has now continued beyond any known historical positions, drastically altering the geomorphic process activity of the environment and shifting zones of hazard initiation (Kääb et al., 2005). Glacial hazards include ice avalanches, glacial floods, and debris flows, although the most catastrophic events have involved complex chain reactions or transformation of mass movements or floods into rapid debris flows (e.g., Huggel et al., 2005). Other hazards can develop directly from surge type glacial movements (Haeberli et al., 2002), while large bedrock failures are increasingly being studied in relation to changing glacial and permafrost conditions (Harris, 2005). Fundamental research into phenomena such as ice avalanches (Alean, 1985), glacier-related debris flows (Rickenmann, 1999) and flooding (Clague and Evans, 2000; Haeberli, 1983; Maizels and Russel, 1992) has come from Canada, Central Europe and Iceland, where populated villages and transport infrastructure extend into the glacial environment. Understanding of such processes and potential impacts in the Mount Cook region of New Zealand is comparatively limited, despite recognition of 20th century glacial recession (Chinn, 1996), associated destabilisation of surrounding terrain and lake formation (Blair, 1994; Hochstein et al., 1995), and the potential for large magnitude chain reaction events involving mass movements into glacial lakes (McSaveney, 2002).

Published by Copernicus Publications on behalf of the European Geosciences Union. 
This paper aims to use remote sensing, geographic information system (GIS) capabilities and flow path modelling to identify potential initiation zones and explore the spatial distribution of potential ice avalanches, debris flows and catastrophic outburst floods in the Mount Cook region of New Zealand. In addition, the first results from numerical modelling of recent rock avalanches are introduced, providing a tool for assessing future impacts from large bedrock failures in the region. The emphasis of this study is on events originating from the current glacierised and recent paraglacial landscape, which is inferred here to be terrain uncovered since the Little Ice Age (LIA) maximum was reached (see Sect. 3). It is beyond the scope of this contribution to provide a hazard assessment. Instead, the primary objective here is to apply conservative, worst-case scenario modelling of potential events, thereby directing future studies towards locations where infrastructure and human activities may be exposed to mass movements and/or flood inundation. Limitations of the approach will be discussed, and the impact of changing glacial conditions will be considered in relation to future event processes.

\section{Background}

Glacial floods refer to the sudden discharge of a water reservoir that has formed either underneath, at the side, in front, within, or at the surface of a glacier (Richardson and Reynolds, 2000). For reservoirs developing as lakes on or at the margin of glaciers, remote sensing at suitable spatial and temporal resolution is an appropriate tool for monitoring hazardous developments (e.g., Huggel et al., 2002). Floods are the most far reaching of all glacial hazards, often initiating from the catastrophic failure of moraine dammed lakes, for which the term glacial lake outburst flood (GLOF) has been adopted (Richardson and Reynolds, 2000). GLOFs frequently transform into hyperconcentrated or debris flow events following the entrainment of paraglacial debris, and are a well documented hazard for Central Asia (Ding and Liu, 1992; Quincey et al., 2007), the Andes (Reynolds, 1992), Canada (Clague and Evans, 2000), and Europe (e.g., Haeberli, 1983). Ice avalanches occur when large masses of ice detach from steep cliff or ramp type glaciers (Alean, 1985) as frontal block failures, slab failures, or deeper failures at the ice/bedrock interface (Richardson and Reynolds, 2000). Relative to glacial floods, ice avalanches typically travel shorter distances and directly affected areas are normally restricted to densely populated alpine regions (Salzmann et al., 2004). However, far reaching disasters have resulted from process interactions involving combined ice/rock avalanches and transformations into debris or mudflows, such as the 1970 Huascaran disaster in Peru (Carey, 2005), or the more recent 2002 Kolka-Karmadon avalanche in the Caucasus (Huggel et al., 2005). Periglacial and recently uncovered paraglacial environments are prone to debris flow initiation because they are characterised by large accumulations of unconsolidated sediment, in the form of moraine deposits and talus slopes (Evans and Clague, 1994). For example, over $50 \%$ of debris flows observed during one particularly severe year in the Swiss Alps initiated from zones that had deglaciated within the previous 150 years (Zimmermann and Haeberli, 1992). Unlike debris flows on lowland hillslopes, glacier-related events can become activated via several mechanisms, including snow or ice melt and high intensity rainfall (Chiarle et al., 2007; Rickenmann and Zimmermann, 1993), permafrost degradation (Harris, 2005), or from catastrophic entrainment within glacial floodwaves (Clague and Evans, 1994; O'Connor et al., 2001).

Although New Zealand has significant areas of mountainous terrain, the population is almost entirely located in lowland areas, and therefore floods and mass movements occurring in high mountain regions have received comparatively less scientific attention. Studies have described flood hazard problems from Franz Josef and Fox Glaciers where the sudden release of sub- or en-glacial reservoirs can mobilise large amounts of sediment (Davies et al., 2003; Goodsell et al., 2005). Debris flow activity initiated during storm events is known to potentially endanger infrastructure within the Mount Cook Village (Skermer et al., 2002; Whitehouse, 1982), and the catastrophic downwasting of large valley glaciers is resulting in widespread moraine wall failure and the destruction of backcountry huts and tracks (Blair, 1994). Ice avalanche activity in the Mount Cook region predominates as low magnitude $\left(<1000 \mathrm{~m}^{3}\right)$, high frequency events (1-8 events/h) from steep cliff-type glaciers (Iseli, 1991), producing a significant hazard on many of the well known climbing routes during the summer ablation season (Irwin et al., 2002). Large bedrock failures from glaciated areas of the Southern Alps have received greater scientific attention (e.g., Korup, 2005a; Whitehouse and Griffiths, 1983), partly because road infrastructure can be at risk (Paterson, 1996), downstream chain reactions can endanger lowland areas (e.g., Davies and Scott, 1997; Hancox et al., 2005), and recent glacial changes appear to be increasing the frequency of high magnitude events and likelihood of impacts into glacial lakes (McSaveney, 2002).

An important development in glacial hazard research has been the implementation of multi-hazard approaches within a GIS environment, integrating remote sensing detection of individual ice, debris and flood hazard sources with combined empirical and hydrological approaches to event path modelling (Huggel et al., 2004). Despite the implied suitability of these approaches to large scale, regional applications, to date, results have mainly been illustrated for casestudy type scenarios within the European Alps. The Mount Cook region of New Zealand's Southern Alps provides an opportunity to implement GIS based procedures across a large, dynamic and diverse region where the primary objective is to gain first order knowledge of glacial hazard potential and recognition of affected areas. Particular emphasis 
is given to glacial lake flooding, and exploring the use of combined remote sensing/GIS methods to distinguish lakes formed within steep morainic debris. In recognition of the importance of large bedrock failures in the region (e.g., McSaveney, 2002; Whitehouse and Griffiths, 1983) this study is expanded beyond GIS based modelling of glacial lake floods, debris flows and ice avalanches, to include a numerical modelling approach that may be used to simulate potential rock avalanche impacts at a more detailed level of investigation.

\section{The Mount Cook region}

The Mount Cook region is broadly defined here to encompass the Aoraki Mount Cook National Park, extending west of the main divide into the Westland National Park and further south towards the Ben Ohau Range, with a total land area of over $3500 \mathrm{~km}^{2}$ (Fig. 1). The region includes the highest mountains and the most heavily glacierised terrain of New Zealand's Southern Alps. Permanent snow covered peaks are found between 2500 and $3754 \mathrm{~m}$, with local relief in the order of 1000-2700 m (McSaveney, 2002). Moist westerly airflow generates high orographic precipitation about the main divide $\left(>12 \mathrm{~m} \mathrm{y}^{-1}\right)$, but an extreme leeward gradient produces $<4 \mathrm{~m} \mathrm{y}^{-1}$ only $20 \mathrm{~km}$ further to the southeast (Henderson and Thompson, 1999). The timing of the LIA maximum varied across the region, but between 1750 and 1890 widespread retreat had begun, becoming most evident during the mid 20th century, and in total, a $49 \%$ loss in ice area has been estimated, although some highly responsive glaciers have advanced recently owing to short term climate variations (Chinn, 1996). The Alpine Fault is a major active fault traversing the northwestern edge of the study area, on which most of the ongoing tectonic movement between the Australian Plate (to the northwest) and the Pacific Plate (to the southeast) is concentrated. Plate convergence across the Australian-Pacific plate causes continued uplift of the Southern Alps in the order of $10 \mathrm{~mm} \mathrm{y}^{-1}$, which is approximately in balance with regional erosion (Koons, 1990). The last major (M 8) earthquake on the Alpine Fault has been dated at 1717 , although the expectation is for episodic shaking from high-magnitude (M7-8) events every 200-300 years, (Wells et al., 1999).

The Mount Cook Village is the main service and accommodation centre for visitors that access the region from the east, with a small permanent population of $\sim 100$ and a larger seasonal component linked to tourism activities in the region. West of the main divide, the largest tourist and residential centres are Franz Josef and Fox Glacier Villages, with 300 permanent residents housed in each village. Figures provided by the Department of Conservation indicate that backcountry hut and camp ground usage in the Mount Cook National Park averaged nearly 10000 bed-nights per year during the monitoring period 1982 to 2002. In the Westland National
Park, 4500 visitors walked the Copland Valley track in 2007 (Fig. 1), and 250000 made the short walk to the terminus of the Fox Glacier (FX), with these numbers slowly increasing over recent years. Main roads connect to all tourist and residential areas, but the nearest transalpine passes are $80 \mathrm{~km}$ to the southwest and $150 \mathrm{~km}$ to the northeast. Numerous unsealed vehicle tracks give access to more remote areas and farm buildings.

\section{Regional hazard modelling}

\subsection{Modelling strategy}

Allen et al. (2008b) applied remote sensing based methods to map the distribution of glacial lakes, ice, and debris accumulations across the Mount Cook region. These procedures used visible, near infrared (NIR) and shortwave infrared (SWIR) bands of the Advanced Spaceborne Thermal Emission and Reflection Radiometer (ASTER) satellite sensor, and were based upon an orthorectified scene of 24 January 2006. The inclusion of topographic information from the Landcare Research L2, 25 m gridded South Island digital elevation model (DEM) enables detection of steep, potentially unstable surfaces on the basis of empirically derived values describing critical slope gradients (Table 1). The DEM is derived from stereographic analyses of 1:50 000 aerial photography captured in 1986, and although errors are strongly related to landform, a root mean square error of 5$8 \mathrm{~m}$ has been calculated for hilly and steep terrain (Barringer et al., 2002).

Potential debris flow, ice avalanche, and flood events were modelled at the regional scale using the modified single flow (MSF) routing algorithm developed by Huggel et al. (2003). Simple GIS spatial queries could then identify where event paths potentially intersect with infrastructure or where interactions such as ice impacts into glacial lakes might occur (Table 2). The MSF model is based on the D8 flow direction algorithm, modified to provide a quasi-qualitative likelihood that a given cell will be affected by the flow path based on distance from the source area, and allowing for deviation of up to the $45^{\circ}$ either side from the path of steepest descent. However, it must be noted that this should not be interpreted as a hazard probability because event frequency and timing is not considered. In addition, the MSF model has no physical basis, and therefore cannot represent more complex behavior of mass movements such as barrier run-up and overtopping. Despite these obvious limitations, the MSF model has proven a useful tool for early recognition of hazard potential, and is particularly well suited for use at larger spatial scales where multiple source areas are identified, and direct field observations may be difficult (e.g., Huggel et al., 2004; Schneider et al., 2008). As with previous studies, a worst-case scenario approach is used, whereby modelled flow paths are continued 


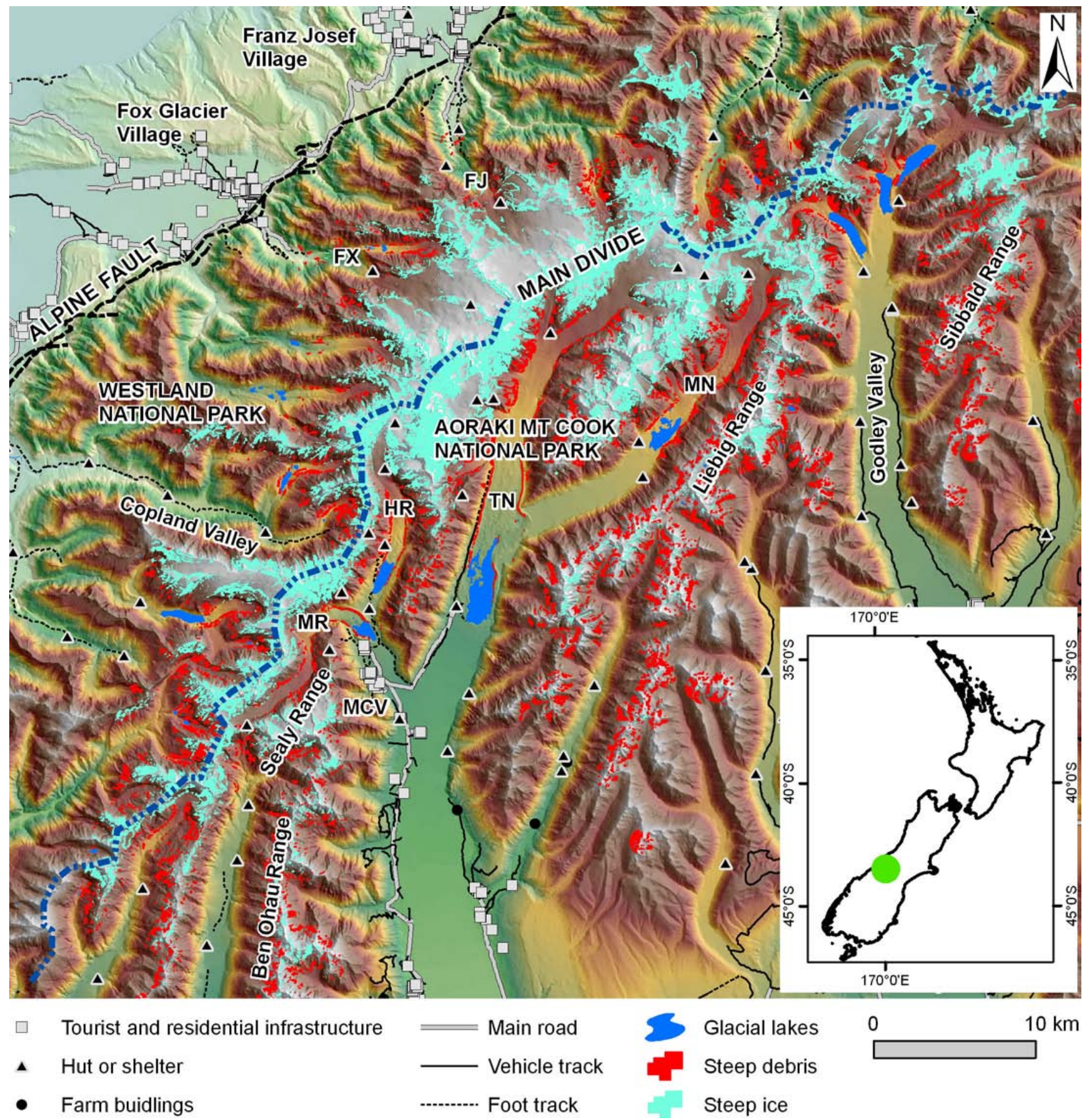

Fig. 1. Overview of the Mount Cook study region showing distribution of road, track, and built infrastructure. Main villages, including the Mount Cook Village (MCV) are identified. Glaciers (abbreviated), river valleys, and mountain ranges referred to in the text are also given. The base image is the colour-shaded relief from the NZ 25 m DTM, with terrain surfaces classified from ASTER satellite imagery, January 2006.

until a probable maximum runout is reached. This maximum runout is described by an angle of reach $\alpha$, which defines the average slope of a line between the starting and end points of a mass movement (Table 1).

\subsection{Glacial lake floods}

Glacial lakes were mapped with ASTER using the Normalised Difference Vegetation Index (NDVI) (NIR3RED2)/(NIR3+RED2), and an additional threshold of 
Table 1. Parameters used to identify potential source areas and defining the maximum probable runout of glacial lake floods, debris flows, and ice avalanches.

\begin{tabular}{|c|c|c|c|}
\hline & Glacial lake floods & Debris flows & Ice avalanches \\
\hline $\begin{array}{l}\text { Surface } \\
\text { characteristics }\end{array}$ & $\begin{array}{l}\text { - Lakes on or at the margins of a glacier } \\
\text { - Expanding lake area } \\
\text { - Steep moraine dammed lakes }\end{array}$ & $\begin{array}{l}\text { - Debris accumulations occurring } \\
\text { within glacial, or recent glacial zones }\end{array}$ & Steep glacial ice \\
\hline $\begin{array}{l}\text { Critical slope } \\
\text { gradient }\end{array}$ & $\begin{array}{l}\text { Sediment entrainment } \\
\text { and hyperconcentration: } \\
-10^{\circ} \\
\text { (Clague and Evans, 1994; } \\
\text { Hungr et al., 2005) }\end{array}$ & $\begin{array}{l}\text { Flow initiation: } \\
-25-38^{\circ} \\
\text { (Hungr et al., 1984; } \\
\text { Rickenmann and Zimmermann, 1993; } \\
\text { Takahashi, 1991) }\end{array}$ & $\begin{array}{l}\text { Temperate ice: } \\
-25^{\circ} \\
\text { Cold ice: } \\
-45^{\circ} \\
\text { (Alean, 1985) }\end{array}$ \\
\hline $\begin{array}{l}\text { Maximum probable } \\
\text { runout }\end{array}$ & $\begin{array}{l}\text { Clear water flood: } \\
- \text { May exceed } 200 \mathrm{~km} \text { and } \\
\text { attain angle of reach }<3^{\circ} \\
\text { GLOF triggered debris flow: } \\
-11^{\circ} \text { angle of reach } \\
\text { (Huggel et al., 2002; } \\
\text { McKillop and Clague, 2007) }\end{array}$ & $\begin{array}{l}-11^{\circ} \text { angle of reach } \\
\text { (Rickenmann, 2005; } \\
\text { Rickenmann and Zimmermann, 1993) }\end{array}$ & $\begin{array}{l}-17^{\circ} \text { angle of reach } \\
\text { (Alean, 1985; } \\
\text { Huggel et al., 2004) }\end{array}$ \\
\hline
\end{tabular}

RED2/GREEN1, providing a useful distinction of all water bodies in the region regardless of turbidity levels (Allen et al., 2008b). In total, 65 glacial lakes were identified but some were small interlinked supraglacial lakes and ponds. To exclude the smallest lakes from the flood modelling, a lake area threshold of $1500 \mathrm{~m}^{2}$ was used, leaving 54 remaining lakes. The majority of lake water exists at low elevations (750-1000 m), where large proglacial lakes have formed on the Murchison (MN), Tasman (TN), Hooker (HR) and Mueller (MR) glaciers east of the main divide (Figs. 1 and 2). Because bathymetric measurements have been limited to piecemeal observations, estimation of lake volumes across the wider region must rely upon relationships describing lake volume as a function of surface area, derived from measurements in Canada, North America, Nepal, Central Europe, and South America (O'Connor et al., 2001; Huggel et al., 2002). The available measurements from the Mount Cook region enable some local validation of these relationships (Table 3). Because it results in significantly smaller errors, the relationship of Huggel et al. (2002) is preferred, albeit with the understanding that actual volumes of large proglacial lakes may be underestimated by $\sim 20-50 \%$ because of the exceptional depths (>55 m) of these lakes compared with the sample from which the relationship was established. The Mueller Lake appears an anomaly, with very shallow depths possibly relating to greater sedimentation into the lake and/or the younger development phase of the lake. The majority of lakes are estimated to have relatively small volumes (modal volume of $0.05 \times 10^{6} \mathrm{~m}^{3}$ ) but 14 lakes have estimated volumes larger than $1 \times 10^{6} \mathrm{~m}^{3}$, with the Tasman Lake containing more than $200 \times 10^{6} \mathrm{~m}^{3}$ (Fig. 3a).

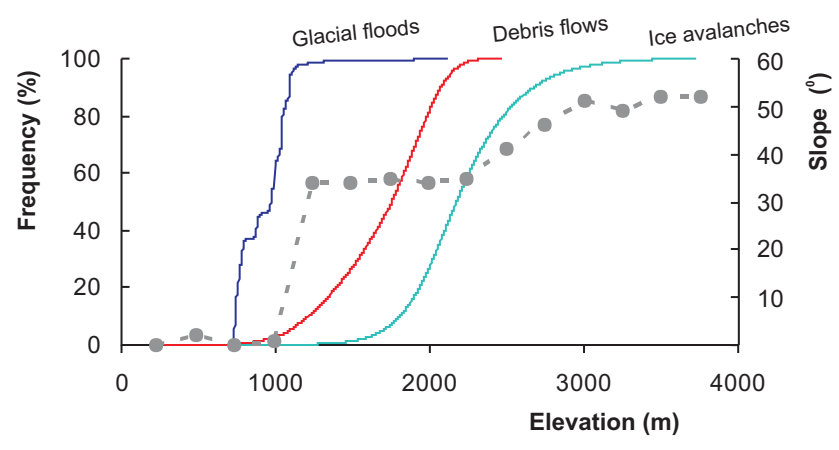

Fig. 2. Cumulative frequency distributions describing source areas for glacial flood and mass movements in the Mount Cook region as a function of elevation. Glacial lake water, steep debris accumulations and steep ice predominate within distinct altitudinal zones, and are compared with the modal topographic slope gradient calculated within $250 \mathrm{~m}$ elevation increments.

Because the majority of glacial lake water in the Mount Cook region is located at lower elevations characterized by gentle slope gradients (Fig. 2), it is considered inappropriate to assume lake failures will transform into debris flow events. Therefore, potential flood events were initially modelled as clear water floodwaves, for which flood attenuation was allowed to continue until the great lakes of Tekapo or Pukaki were reached in the east, or until the ocean was reached in the west. In fact, travel distances in excess of $200 \mathrm{~km}$ have been recorded in the Karakorum Himalaya from glacial floodwaves (Hewitt, 1982). In a second step, the modelled flood paths were analysed to identify outlet channel areas 
Table 2. Summary of MSF modelling results, giving the extent of human infrastructure intersecting with modelled flow paths for the worstcase probable maximum runout. Also provided is the number of glacial lakes positioned within incoming flow paths, giving an indication of where potential flow transformations or impact waves might be initiated. Modelling was repeated for reduced runout scenarios, with minimum $\alpha$ increased by 50 and $100 \%$.

\begin{tabular}{|c|c|c|c|c|c|c|c|}
\hline & $\begin{array}{l}\text { Tourist or } \\
\text { residential dwellings }\end{array}$ & $\begin{array}{l}\text { Remote } \\
\text { buildings }\end{array}$ & $\begin{array}{l}\text { Main } \\
\text { roads }\end{array}$ & $\begin{array}{l}\text { Vehicle } \\
\text { tracks }\end{array}$ & $\begin{array}{l}\text { Foot } \\
\text { tracks }\end{array}$ & Power/phone & $\begin{array}{l}\text { Lake } \\
\text { impacts }\end{array}$ \\
\hline \multicolumn{8}{|l|}{ Glacial Floods } \\
\hline i) Clear water & $\begin{array}{l}\text { Mount Cook Village (MCV) } \\
\text { and airport. } \\
\text { Floodplains southwest } \\
\text { of Fox Glacier village. }\end{array}$ & 3 huts & $17 \mathrm{~km}$ & $29 \mathrm{~km}$ & $3 \mathrm{~km}$ & $12 \mathrm{~km}$ & 6 lakes \\
\hline $\begin{array}{l}\text { ii) Debris flows } \\
11^{\circ}(\tan \alpha=0.19)\end{array}$ & NIL & NIL & NIL & NIL & NIL & NIL & NIL \\
\hline \multicolumn{8}{|l|}{ Debris Flows } \\
\hline $11^{\circ}(\tan \alpha=0.19)$ & $\begin{array}{l}\text { MCV and locations } \\
\text { along main access road. } \\
\text { Glentanner Airport. }\end{array}$ & $\begin{array}{l}17 \text { huts } \\
1 \text { shelter } \\
1 \text { farm bld }\end{array}$ & $17 \mathrm{~km}$ & $33 \mathrm{~km}$ & $37 \mathrm{~km}$ & $3 \mathrm{~km}$ & 41 lakes \\
\hline $\begin{array}{l}+50 \% \\
16.5^{\circ}(\tan \alpha=0.30)\end{array}$ & $\mathrm{MCV}$ & $\begin{array}{l}13 \text { huts } \\
1 \text { farm bld }\end{array}$ & $8 \mathrm{~km}$ & $22 \mathrm{~km}$ & $31 \mathrm{~km}$ & $2 \mathrm{~km}$ & 34 lakes \\
\hline $\begin{array}{l}+100 \% \\
22^{\circ}(\tan \alpha=0.40)\end{array}$ & $\mathrm{MCV}$ & $\begin{array}{l}10 \text { huts } \\
1 \text { farm bld }\end{array}$ & $2 \mathrm{~km}$ & $16 \mathrm{~km}$ & $21 \mathrm{~km}$ & NIL & 25 lakes \\
\hline \multicolumn{8}{|l|}{ Ice Avalanches } \\
\hline $17^{\circ}(\tan \alpha=0.31)$ & NIL & $\begin{array}{l}10 \text { huts } \\
2 \text { shelters }\end{array}$ & NIL & $1 \mathrm{~km}$ & $30 \mathrm{~km}$ & NIL & 36 lakes \\
\hline $\begin{array}{l}+50 \% \\
25.5^{\circ}(\tan \alpha=0.48)\end{array}$ & NIL & $\begin{array}{l}7 \text { huts } \\
1 \text { shelter }\end{array}$ & NIL & NIL & $23 \mathrm{~km}$ & NIL & 26 lakes \\
\hline $\begin{array}{l}+100 \% \\
34^{\circ}(\tan \alpha=0.67)\end{array}$ & NIL & NIL & NIL & NIL & $4 \mathrm{~km}$ & NIL & 11 lakes \\
\hline
\end{tabular}

characterized by steep debris, and if appropriate, runout distances could then be re-evaluated for possible debris flow scenarios. A secondary output from the MSF model provides the horizontal distance along the flood path from the lake source. For floods originating from moraine breaches in the Three Sisters Range, Oregon, O'Connor et al. (2001) established $500 \mathrm{~m}$ as the horizontal distance in which floodwaves transformed into debris flow via sediment entrainment. This distance will be highly variable depending on local topography and channel morphology, but $500 \mathrm{~m}$ is taken here to arbitrarily encompass the dam and surrounding outlet channel areas for all glacial lakes (Fig. 4a).

ASTER-based methods were used to map debris and vegetation coverage within the lake outlet areas, supported by higher resolution satellite imagery and field photography. Large debris accumulations across the region have previously been identified and distinguished from bedrock using an image texture algorithm (Allen et al., 2008b). This idea stems from novel approaches developed with higher resolution im- agery in the Swiss Alps (Huggel et al., 2004) and recognizes the uniformity of a debris surface compared to the rough, angular appearance of bedrock. The success of the procedure becomes more limited when applied with lower resolution ASTER imagery, but larger talus slopes, moraine deposits and outwash gravels were all identified. Vegetated surfaces were mapped using the NDVI. In a first step, outlet areas containing less than a combined $20 \%$ coverage of vegetation or debris were considered to be non-debris. For all other outlets, a larger presence of vegetation or non-vegetated debris was considered to indicate alluvium or moraine composition. If the vegetation abundance relative to non-vegetated debris exceeded $75 \%$, the outlet area was categorized as 'vegetated' otherwise the outlet was categorized as "debris". A mean slope threshold of $10^{\circ}$ was used to further distinguish steep outlet areas in which sediment entrainment is considered likely, based on debris flow studies of Hungr et al. (1984) and observations of GLOF events in Canada (Clague and Evans, 1994). 
Table 3. Comparison between measured and estimated proglacial lake volumes in the Mount Cook region using two different empirical relationships.

\begin{tabular}{|c|c|c|c|c|c|c|c|c|c|}
\hline \multirow[t]{2}{*}{ Lake } & \multirow[t]{2}{*}{$\begin{array}{l}\text { Observation } \\
\text { year }\end{array}$} & \multirow[t]{2}{*}{ Reference } & Area & $\begin{array}{l}\text { Mean } \\
\text { depth }\end{array}$ & Volume & \multirow{2}{*}{$\begin{array}{l}\text { Estimated } \\
\text { volume }^{1} \\
\left(\mathrm{~m}^{3} 10^{6}\right)\end{array}$} & \multirow{2}{*}{$\begin{array}{l}\text { Estimated } \\
\text { volume } \\
2 \\
\left(\mathrm{~m}^{3} 10^{6}\right)\end{array}$} & \multirow{2}{*}{$\begin{array}{l}\text { Error }{ }^{1} \\
(\% *)\end{array}$} & \multirow{2}{*}{$\begin{array}{l}\text { Error }^{2} \\
(\% *)\end{array}$} \\
\hline & & & $\left(\mathrm{m}^{2} 10^{6}\right)$ & (m) & $\left(\mathrm{m}^{3} 10^{6}\right)$ & & & & \\
\hline \multirow[t]{2}{*}{ Tasman } & 1993 & Hochstein et al. (1995) & 2.0 & 71 & 139 & 89 & 647 & -36 & 365 \\
\hline & 2002 & Röhl (2005) & 3.5 & 75 & 263 & 205 & 2075 & -22 & 689 \\
\hline \multirow[t]{2}{*}{ Hooker } & 1995 & Warren and Kirkbride (1998) & 0.7 & 55 & 41 & 23 & 95 & -44 & 132 \\
\hline & 2002 & Röhl (2005) & 0.9 & 65 & 59 & 30 & 140 & -49 & 137 \\
\hline Mueller & 2002 & Röhl (2005) & 0.5 & 9 & 4.3 & 12 & 40 & 340 & 830 \\
\hline Maud & 1994 & Warren and Kirkbride (1998) & 1.3 & 62 & 78 & 48 & 271 & -38 & 247 \\
\hline Godley & 1994 & Warren and Kirkbride (1998) & 1.7 & 62 & 102 & 70 & 464 & -31 & 355 \\
\hline
\end{tabular}

${ }^{1}$ Estimate based on the equation of Huggel et al. (2002), where lake volume $(V)$ in $\mathrm{m}^{3}$ is expressed by the relationship:

$V=0.104 A^{1.42}$.

${ }^{2}$ Estimate based on the equation of O'Connor et al. (2001) where lake volume $(V)$ in $\mathrm{m}^{3}$ is expressed by the relationship:

$V=3.114 A+0.0001685 A^{2}$ where $(A)$ is lake area in $\mathrm{m}^{2}$.

* Error is calculated as the difference between measured and estimated volumes, divided by the measured volume.

The majority of outlet areas were classified as "debris", with only one non-debris (bedrock) outlet identified. Lakes formed within debris mantled glacial ice could not be automatically excluded from the classification. These lakes have small volumes, and occur on low gradient supraglacial areas of the larger valley glaciers. Nearly $70 \%$ of terrain contained within outlet channel areas is characterized by slope gradients less than $10^{\circ}$ (Fig. 3b), but several examples of lakes formed within steep vegetated and non-vegetated morainic debris occur in cirque basins primarily east of the main divide. In these instances, potential debris flow initiation is considered possible, and paths were therefore remodelled using a maximum runout defined by an $11^{\circ}$ angle of reach recognized from GLOF triggered debris flow observations in the European Alps and Canada (Huggel et al., 2002; McKillop and Clague, 2007). Relative to modelled clear water floodwaves, flood triggered debris flows all appear to terminate well before huts, vehicle tracks, or other infrastructure are reached (Fig. 5, Table 2). Because the MSF model does not consider wave height and barrier overtopping cannot be simulated, the modelled floodwave down the Godley River is initially confined within a shallow channel leading from the lake outlet. However, evidence from a flood event which occurred from a rock avalanche impact in 1992 indicated that a 7-10 m high wave completely inundated the flat area surrounding the lake outlet before rapidly dispersing downstream on the wide braided river plains (McSaveney, 2002).

Vegetated outlet areas characterize most large proglacial lakes which have formed within low gradient moraine and outwash gravels during the past two decades (e.g., Figs. 4c and $7 \mathrm{~b}$ ). The presence of vegetation implies some longer

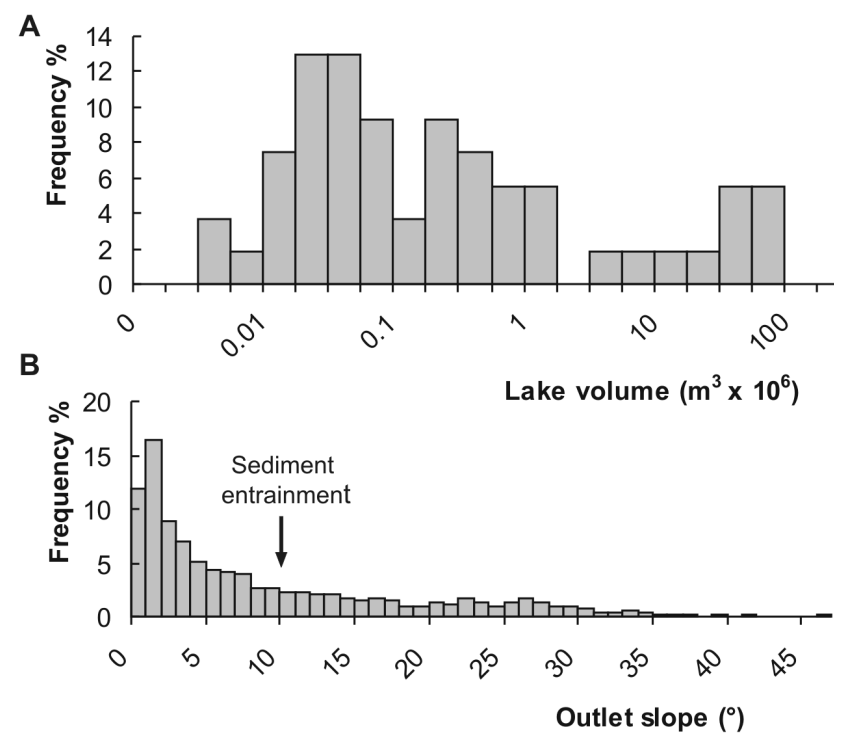

Fig. 3. A Frequency distribution of glacial lake volumes in the Mount Cook region, January 2006, estimated from ASTER mapped lake areas using an empirical relationship between lake area and volume (after Huggel et al., 2002). B Frequency distribution of slope gradients for all pixels contained within and surrounding lake outlet channel areas.

term stability of the outlet area, given that no recent disturbances are likely to have occurred. This is exemplified by the Maud Glacier lake (Fig. 4b), where the current lack of vegetation provides evidence of the flood event that occurred 26 years previously. Also, vegetation can reduce the 

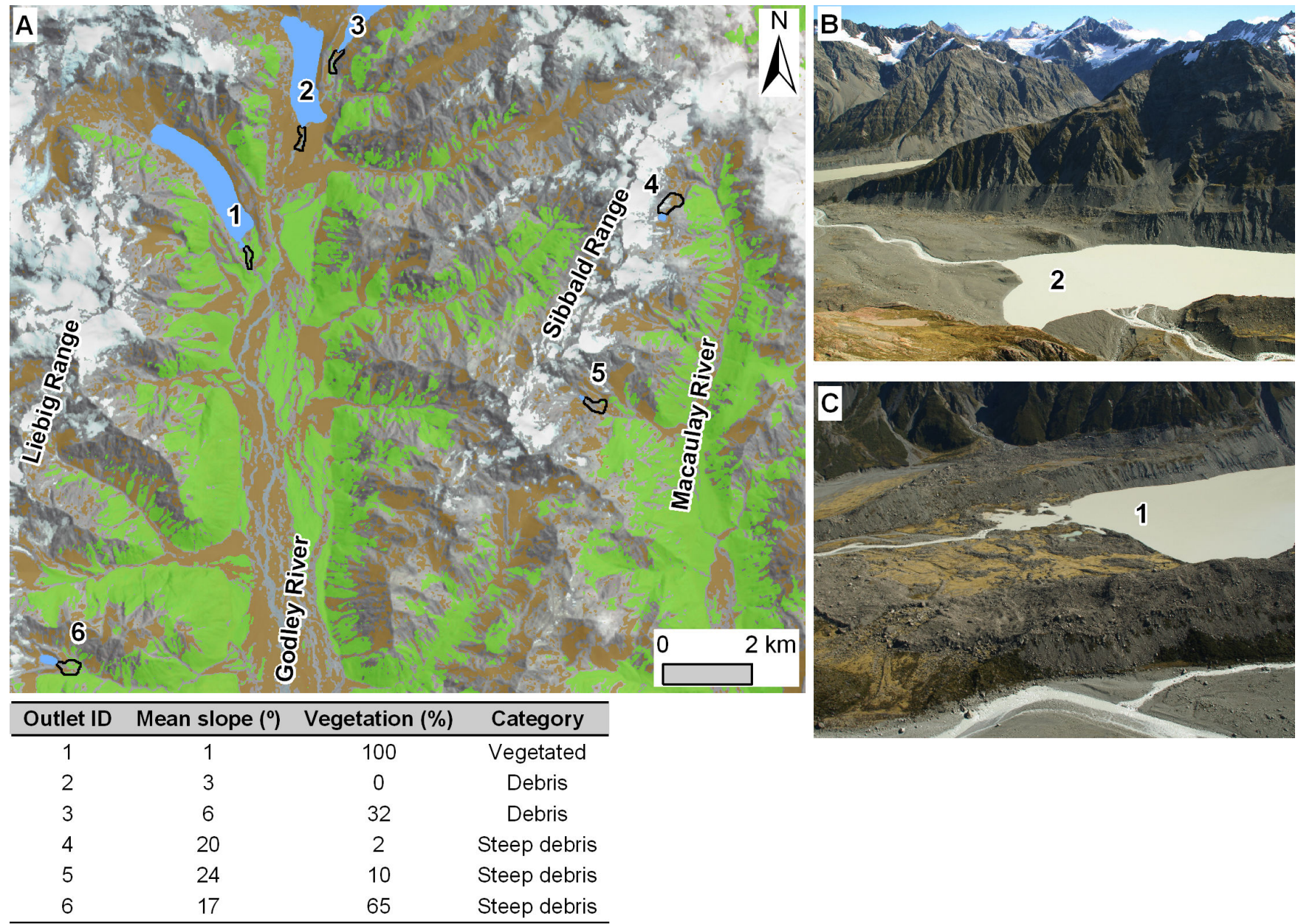

Fig. 4. A Classification of lake outlet areas (black outline) using ASTER based mapping of debris (brown) and vegetated surfaces (green). Unclassified areas predominantly represent bedrock, glacial ice, and river water. Vegetation coverage (\%) is calculated relative to unvegetated debris. B The outlet area of the Maud Lake has been scoured of vegetation following the 1992 Mt Fletcher rock avalanche initiated floodwave, while at the Classen Lake $\mathbf{C}$ the presence of grass and tussock suggests no recent disturbances have occurred (photos: S. Winkler, April 2008).

erodibility of the channel area, limiting the likelihood of natural dam failure. However, when considering worst-case scenarios, future dam overtopping from displacement waves generated by mass movement impacts cannot be excluded. This would be most concerning where permanent building and road infrastructure are positioned within the flood plains of larger volume lakes, which occurs on the West Coast southwest of Fox Glacier Village, and along the road leading into Mount Cook Village (Table 2).

\subsection{Debris flows}

Steep ASTER classified debris accumulations that might give rise to a flow event were distinguished within a $25-38^{\circ}$ slope range. Although specific to the source lithology involved and the associated angle of repose, this slope range typifies starting conditions observed internationally for debris flow events (e.g., Hungr et al., 1984; Rickenmann and Zimmermann,
1993), and corresponds to slope gradients measured for talus slopes in the Southern Alps of New Zealand (Dunning, 1996; Whitehouse and McSaveney, 1983). Steep debris accumulations are widespread across the region, but the emphasis of this study is towards situations where current and recent glacial processes directly influence debris accumulation and where ice or perennial snow melt can lead to flow initiation. To achieve this focus, a GIS buffer was used, extracting all debris accumulations within a maximum distance of $750 \mathrm{~m}$ from ASTER mapped glacial ice, including manually digitized debris covered ice. This distance is based upon average glacial length changes observed throughout the Southern Alps since the LIA, and also encompasses the likely extent of vertical recession over this time (Chinn, 1996). To remove isolated pixels, debris accumulations used as input into the MSF model were restricted to a minimum area of $1 \times 2$ pixels, or $\sim 1250 \mathrm{~m}^{2}$, representing areas of lateral moraine above the downwasting valley glaciers, terminal moraine deposits from 


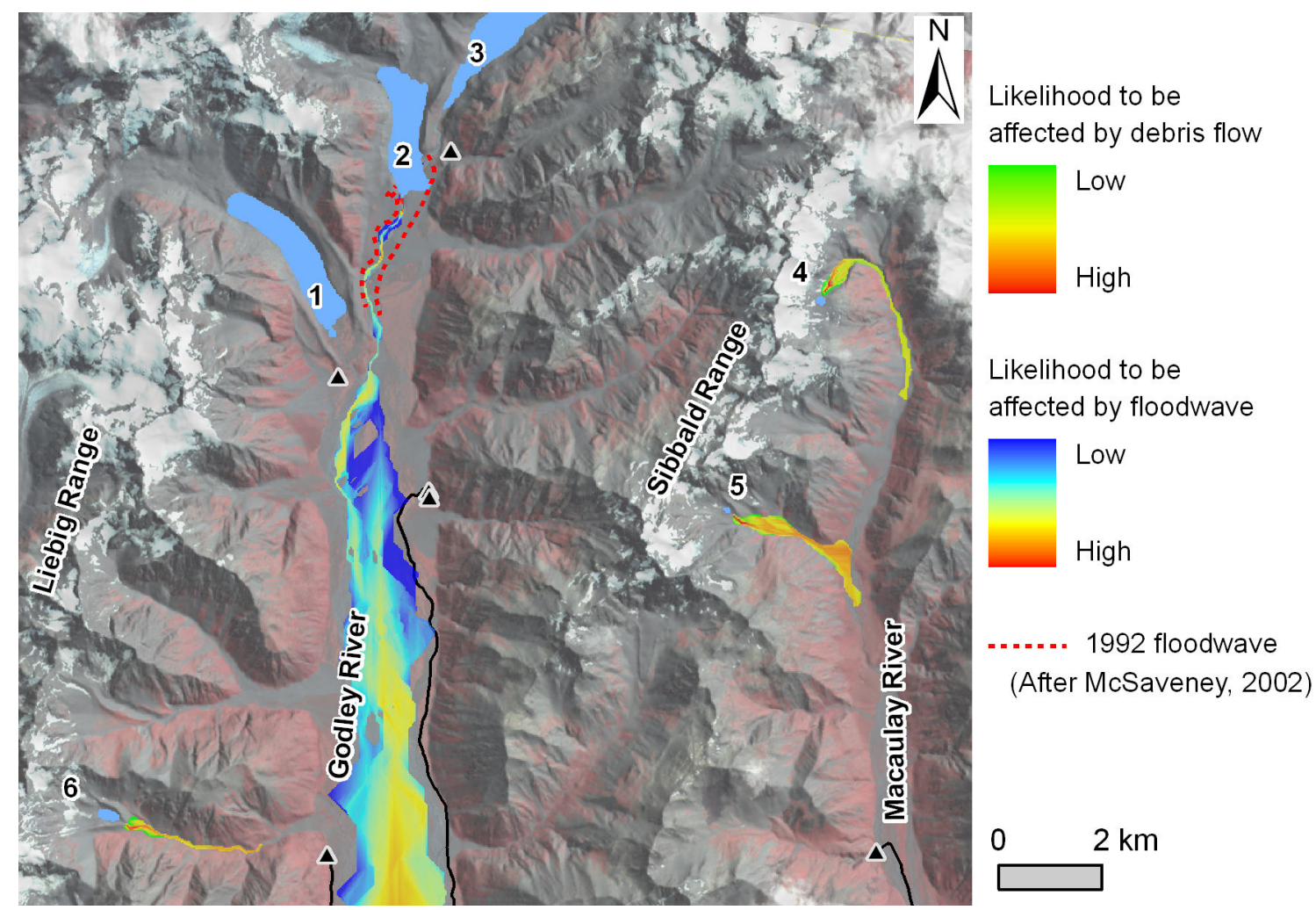

Fig. 5. MSF modelling of potential GLOF triggered debris flow events from 3 unnamed lakes where the dam area and outlet channel is formed within steep morainic debris (see Fig. 4). Also modelled is the most likely path for a floodwave initiating from the Maud Glacier lake (2). In 1992, a rock avalanche from Mt Fletcher produced a displacement wave from this lake. The background is provided by a 2006 ASTER image.

steeper glaciers, cirque glacial moraines, and talus slopes beneath glaciers or large perennial snow patches (Fig. 1).

The most comprehensive observations of debris flow travel distances in alpine terrain comes from the Swiss Alps, where a minimum $\alpha=11^{\circ}(\tan \alpha=0.19)$ has been recognized for coarser grained flows (Rickenmann and Zimmermann, 1993), and subsequently used to define the maximum runout for modelled periglacial events (Huggel et al., 2004). Application of this worst-case scenario to potential events in the Mount Cook region identifies large sections of roading, tracks, huts, shelters and farm buildings positioned within modelled debris flow paths (Table 2). This is particularly evident east of the main divide, where a drier climate favours extensive talus development (Whitehouse, 1988) and vehicle tracks extend higher into the headwaters of braided river valleys (Fig. 1). Built infrastructure located within the Mount Cook Village, and nearby roading appears to intersect with potential paths originating from high on the Sealy Range where remnant cirque glaciers and perennial snow remain (Fig. 6). However, the maximum probable runout distance for these events exceeds any recognized threat to the village (McSaveney and Davies, 2005) and appears to overestimate flow propagation far beyond the composite fans upon which infrastructure is located. Minimum and maximum slope gradients observed on these fans range from $<2$ to $7^{\circ}$. West of the main divide, narrow steep gorges transport potential flows originating in the glacierised catchments down towards, but stopping short of directly reaching the state highway. In these instances, temporary blockage, dambreak, and remobilization of debris are possible within the confines of a steep gorge, and hence, a far reaching hazard potential may exist to not only the road, but villages such as Franz Josef located nearby (e.g., Davies and Scott, 1997).

Application of the MSF for multiple events at the regional level allows only a single worst-case maximum runout parameter, but an alternative estimate for individual events might consider available catchment area $\left(A_{c}\right)$ above the debris source. For this purpose, $\tan \alpha=0.20 A_{c}^{-0.26}$ has been used to describe the minimum $\alpha$ observed for debris flows in alpine areas of Switzerland and Canada (Rickenmann, 2005). Based on catchment areas calculated using ArcGIS watershed function, a significantly reduced maximum runout is estimated for modelled events affecting the Mount Cook Village and nearby areas (Fig. 6). For example, with a catchment area of $\sim 0.09 \mathrm{~km}^{2}$, a potential event originating from talus debris in the upper reaches of Kitchener Creek establishes a minimum $\tan \alpha=0.37$, although this reach is still in excess of 300-500 $\mathrm{m}$ beyond any recent aggradation visi- 



Fig. 6. A MSF modelling of selected debris flows initiating from glacial zones. The flow paths are terminated using the maximum probable runout defined by a minimum $\alpha=11^{\circ}$ ( $\tan \alpha=0.19$ ). Additional runout distances are indicated, corresponding to a minimum $\alpha$ increase of $50 \%(\tan \alpha=0.30)$ and $100 \%(\tan \alpha=0.40)$, and also using a minimum $\alpha$ related to catchment area (after Rickenmann, 2005). B Closer inspection of a potential source area from a snow covered talus slope at the head of Kitchener Creek (KN), and $\mathbf{C}$ deposition area with village infrastructure located towards lower right. High resolution QuickBird image is from 4 May 2006. 


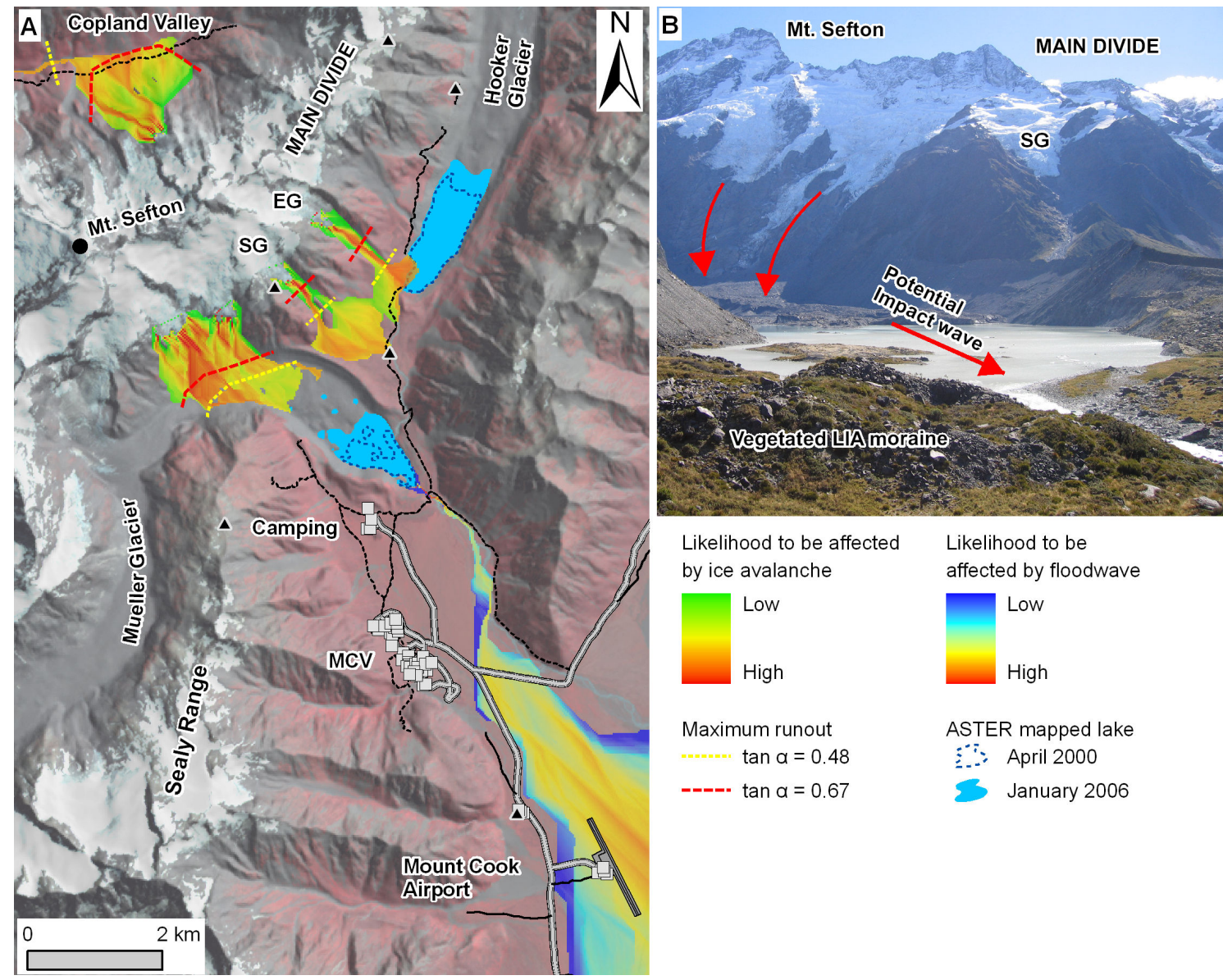

Fig. 7. A MSF modelling of selected ice avalanches affecting the lower Mueller and Hooker Glaciers, and upper Copland Valley. The flow paths are terminated using the maximum probable runout defined by a minimum $\alpha=17^{\circ}(\tan \alpha=0.31)$. Additional runout distances are indicated, corresponding to a minimum $\alpha$ increase of $50 \%(\tan \alpha=0.48)$ and $100 \%(\tan \alpha=0.67)$. A potential flood path propagating from the Mueller Lake is also shown. B Outlet area of the Mueller Lake looking towards the main divide, indicating potential ice avalanche trajectories towards the lake from beneath Mt Sefton (photo: S. Allen, April 2008).

ble on the stream fan (Fig. 6b, c). Artificial banks have constrained the recent flow of Kitchener creek to the north, but this was only considered a temporary measure and unlikely to mitigate a high magnitude debris flow event (McSaveney and Davies, 2005). While the $A_{c}$ approach provides a secondary estimate with which the static $\tan \alpha=0.19$ scenario can be quickly compared, it makes no consideration of geological, hydrological, and glaciological conditions which ultimately govern debris flow potential within an alpine catchment (Rickenmann and Zimmermann, 1993). For example, faults dissecting the Sealy range and many other steep slopes throughout the region form zones of weak shattered rock, from which enhanced sediment delivery can be expected (Korup, 2004). The future loss of remaining glacial ice and perennial snow in these ranges will expose new rock masses to weathering, and uncover further accumulations of morainic debris.

\subsection{Ice avalanche and lake interactions}

ASTER-based mapping of glacial ice has been achieved using a single band ratio (NIR3/SWIR4), providing the best distinction of glacial surfaces in steep, rocky terrain (Allen et al., 2008b). Debris covered tongues are not included within the automated classification, but these areas occur predominantly on low elevation gentle slopes and are therefore unlikely to be significant in relation to avalanche hazard. Modelling potential ice instabilities originating from $>400 \mathrm{~km}^{2}$ of glacier covered terrain is extremely difficult because important indicators such as crevasse patterns, ice displacements, hydrological and thermal conditions are best established through local scale analyses and field studies (e.g., Wegmann et al., 2003). At the regional scale, approaches have applied fundamental empirical observations from the Swiss Alps relating ice instability to topographic slope gradient (Alean, 1985), with a slope threshold of $25^{\circ}$ used to classify potentially unstable steep ice (Huggel et al., 2004; 
Salzmann et al., 2004). In reality, cold based ice, as occurs on steep cliffs and beneath the frontal section of many hanging glaciers at elevations where ground temperature remains $<0^{\circ} \mathrm{C}$ (above $\sim 2500-3000 \mathrm{~m}$ ) (Allen et al., 2008a), should remain stable at higher slope gradients (Table 1). However, the application of a single slope threshold is considered an appropriate worst-case scenario where polythermal glaciers are likely to occur. Steep glacial ice in the region predominates above $2000 \mathrm{~m}$ where modal slope gradients significantly increase (Fig. 2). To restrict the analyses to the largest potential events and exclude isolated seasonal snow, only glacial areas $>2500 \mathrm{~m}^{2}$ were used as input to the MSF model. The modelled avalanche runouts were terminated when a minimum $\alpha=17^{\circ}(\tan \alpha=0.31)$ was achieved, corresponding to observed values in the Swiss Alps (Alean, 1985).

The smaller reach of ice avalanches combined with initiation zones which are generally located higher within the alpine valleys, excludes potential events from reaching any village infrastructure or major roads, and only a small section of the Ball Shelter vehicle track is located within the path of a far reaching event (Table 2). However, backcountry huts/shelters, and foot tracks located in closer proximity to starting zones are intersected by ice avalanche paths, as evident in the lower areas of the Hooker and Mueller Glaciers (Fig. 7). In these instances, events originating from the tongues of the Stocking (SG) and Eugenie (EG) Glaciers must travel the maximum probable distance to reach areas of human activity, while in the upper Copland Valley, smaller travel distances are sufficient to reach the walking track. Ice avalanches from the steep cliff glaciers beneath Mount Sefton frequently deposit onto the lower Mueller Glacier (Iseli, 1991), but these low magnitude events do not exceed a runout beyond a minimum $\tan \alpha=0.67$. However, a proglacial lake is currently expanding towards the ice cliffs, increasing the future potential for displacement waves, particularly from a larger magnitude event, with direct implications for adventure tourism activities operating on or near to the lake.

Ice avalanches on the lower Mueller Glacier are one example of the potential (current or future) for mass movements of ice, rock or debris to produce displacement waves, and lake flooding. A large proportion of lakes in the region show potential for interaction with incoming mass movements from ice and debris (Table 2), and bedrock instabilities are common from steep slopes of the main divide (e.g., McSaveney, 2002). The potential hazard from mass movements of ice (and/or rock) depositing into the Mueller Lake is exemplified because of the rapid enlargement of the lake over recent years, close proximity to the Mount Cook Village, and visitor infrastructure surrounding the lake (Fig. 7). In addition, incoming mass movements from the main divide can enter the Mueller Lake in line with the longitudinal axis of the lake, enabling wave energy to propagate directly towards the outlet channel. At other large proglacial lakes, on the Tasman, Hooker, and Murchison Glaciers, lakes have formed parallel to the mountain slopes, so that incoming mass movements are possible only from the lake sides, in which case, significant wave energy will be dissipated on the opposing bank. The Mueller Lake has formed within LIA moraines, which extend up to $150 \mathrm{~m}$ higher than the lake level on the true right hand side, providing a natural defense structure for the camping area and village located in behind. Nearer the outlet channel, the moraine is only $10-30 \mathrm{~m}$ higher than the lake level, and following some initial confinement, the modelled floodwave quickly disperses on the low gradient alluvial fan, intersecting with main roads and infrastructure of the Mount Cook airport, from where tourist flights operate. Low slope gradients in all the braided river valleys suggest that transformations into debris flows within the flood path from any larger proglacial lake are unlikely.

\section{Rock avalanche modelling}

Most steep rock walls in the Mount Cook region are heavily fractured and dilated, while many have become oversteepened as a result of glacial plucking and subsequent late Holocene ice retreat from their lower flanks (McSaveney, 2002). Given the possibility for rock avalanches to deposit into expanding proglacial lakes, and the potential for rivers to become blocked, leading to catastrophic dam failure and secondary mass movement hazards (Davies and Scott, 1997; Korup, 2005b), appropriate methods at a reduced spatial scale are needed to assess rock avalanche impacts. For simulating individual avalanche events, advanced twodimensional mass movement modelling approaches are well suited for recognition of detailed flow patterns and dynamics. A numerical rapid mass movement model (RAMMS) developed by the WSL Institute for Snow Avalanche Research, Davos Dorf, Switzerland, meets these requirements, and the simulated output is easily integrated into a GIS environment (Christen et al., 2008). This physically based dynamic model uses a finite volume scheme to solve the 2-D shallow water equations for granular flows. The frictional resistance $S_{f x}$ in x-direction and $S_{f y}$ in y-direction which is acting against gravitational acceleration, is described by using a Voellmy approach which incorporates a dry Coulomb friction $\mu$ and a turbulent friction $\xi$ (Bartelt et al., 1999):

$$
\begin{aligned}
& S_{f x}=\left[g H \mu \cos \alpha+\frac{g \cos \alpha\left(U_{x}^{2}+U_{y}^{2}\right)}{\xi}\right] \frac{U_{x}}{\sqrt{U_{x}^{2}+U_{y}^{2}}} \\
& S_{f x}=\left[g H \mu \cos \alpha+\frac{g \cos \alpha\left(U_{x}^{2}+U_{y}^{2}\right)}{\xi}\right] \frac{U_{y}}{\sqrt{U_{x}^{2}+U_{y}^{2}}}
\end{aligned}
$$

where $g$ is the gravitational acceleration, $H$ the flow height, $\alpha$ the slope angle, and $U_{x}$ and $U_{y}$ the velocity components in $\mathrm{x}$ - and $\mathrm{y}$-direction respectively. Details concerning momentum balance and mass conservation equations, including the matter of erosion are described by Christen et al. (2008). 
The RAMMS code is based on extensive experiments within snow avalanche chutes (Kern et al., 2004) and field-based measurements (Sovilla et al., 2006), but the model is also intended to simulate mass movements other than pure snow avalanches, including large rock/ice avalanche events. Here, these model capabilities are illustrated for the first time in relation to a large rock-ice avalanche event which led to lake outburst flooding, and two smaller recent rock avalanches in the Mount Cook region.

In May and September of 1992, two separate rock avalanches with a combined volume of $\sim 11 \times 10^{6} \mathrm{~m}^{3}$ fell from the summit area of Mount Fletcher, depositing into a nearby proglacial lake, producing floodwaves that traveled $35 \mathrm{~km}$ down the Godley Valley, damaging a vehicle track. Both events followed a similar path, and for numerical modelling an initial starting volume of $8 \times 10^{6} \mathrm{~m}^{3}$ was selected, corresponding to estimates completed for the May event (McSaveney, 2002). Average density was set to $2200 \mathrm{~kg} \mathrm{~m}^{-3}$ representing typical greywacke bedrock $\left(2650 \mathrm{~kg} \mathrm{~m}^{-3}\right)$ mixed with minor amounts of ice and firn $\left(500-900 \mathrm{~kg} \mathrm{~m}^{-3}\right)$ which were present in the source area. The density remains constant in the model, so that any desegregation of the material during the flow process and within the deposition volume should be considered when interpreting the results. Furthermore, entrainment was not included as there was no data available to support the likely magnitude involved. However, erosion of glacial ice might have played a significant role, especially during the first impact of the rock material on the glacial surface, which possibly increased the avalanche volume in the order of $10^{5}-10^{6} \mathrm{~m}^{3}$.

Unlike simple hydrologically driven GIS approaches such as the MSF model, RAMMS is able to reflect the physical energetic characteristics of the moving mass, including barrier run-up, overtopping, and deflection, which are all important considerations for local scale modelling. This is most evident midway along the rock avalanche path where the flow travels $\sim 350 \mathrm{~m}$ up the true left flank of the valley, before the majority of the mass deflects back towards the opposite wall, and then down the glacier into the lake (Fig. 8). A component of the mass reaches and overtops the ridge crest, spilling towards but stopping just short of the adjacent Godley Lake. This spillover and other lateral spreading characteristics at the lower section of the flow were used to calibrate the model geometrically. Velocity calibration was achieved on the basis of available seismic data, although the exact duration of the avalanche $(\sim 180 \mathrm{~s})$ was not clearly derived from the seismogram as the collapse was progressive (McSaveney, 2002). The best fit frictional parameters for the Mt. Fletcher avalanche were achieved using $\mu=0.19$ and $\xi=2100 \mathrm{~m} \mathrm{~s}^{-2}$.

Modelled maximum flow heights correspond well with areas of run-up and the general flow direction as indicated by McSaveney (2002), although the initial run-up height and spillover extent is slightly overestimated by the model. Exaggerated spread of the flow from the initiation area results from the modelled release of the detachment mass on top of the topography, rather than from within the rock face as occurs in reality. Modelled maximum flow velocities of $102 \mathrm{~m} \mathrm{~s}^{-1}$ below the area of initial run-up corresponds to estimates of $\sim 120 \mathrm{~m} \mathrm{~s}^{-1}$ made by McSaveney (2002), while modelled mass entry into the lake occurred at a maximum velocity of $20 \mathrm{~m} \mathrm{~s}^{-1}$. By isolating the area of the flow that intersects with the lake and observing the maximum flow heights from within this zone, an estimation of the volume deposited into the lake was made. For the $8 \times 10^{6} \mathrm{~m}^{3}$ event, only $0.76 \times 10^{6} \mathrm{~m}^{3}$ was calculated to enter the lake. Although no measurement of the actual deposit into the lake has been possible, given the absence of any dam freeboard height (Fig. 4b) and the seiching effect of the impact wave, it is not unexpected that a displaced water volume several orders of magnitude greater than the incoming mass was recorded.

The capability of RAMMS to simulate avalanches at a much reduced volumetric magnitude was tested by modelling the two recent Vampire Peak rock avalanches described by Cox and Allen (2009). These events occurred in early summer 2003 and January 2008, with both having similar failure volumes of $1-2 \times 10^{5} \mathrm{~m}^{3}$, and deposition volumes approaching $3 \times 10^{5} \mathrm{~m}^{3}$. The initiation areas were located between 2500 and $2600 \mathrm{~m}$, and were separated by a horizontal distance of less than $150 \mathrm{~m}$. Average density was set to $2650 \mathrm{~kg} \mathrm{~m}^{-3}$ for both events, as there was no surface ice present in the source areas. The modelled flow paths accurately reflect the stronger run-up of the 2008 event, as it rose up to $80 \mathrm{~m}$ across a spur above the Bannie icefall (Fig. 9). Wider lateral spread of the 2008 flow immediately below the detachment resulted in reduced maximum flow heights, compared to the straighter, more direct path of the 2003 event. The runout distance of the 2008 event was also smaller, most probably relating to altered surface friction resulting from the presence of the earlier avalanche deposit. In the RAMMS model these differences were addressed using altered frictional input parameters. While the Coulomb friction $\mu$ was set to 0.14 for both avalanches, the turbulent friction $\xi$ was set to $3000 \mathrm{~m} \mathrm{~s}^{-2}$ for the 2003 event and to $2000 \mathrm{~m} \mathrm{~s}^{-2}$ for the 2008 event. With the lower $\xi$-value for the second event, the avalanche mobility is sufficiently reduced, terminating $\sim 400 \mathrm{~m}$ earlier then the 2003 event.

The limitations of using a $25 \mathrm{~m}$ resolution DEM for modelling low volume avalanche events were partially solved by resampling the elevation data to a $10 \mathrm{~m}$ grid. Although this method does not improve the underlying DEM accuracy, it does enable a higher level of precision in dynamic avalanche modelling. However, the results must be evaluated carefully considering that the geometry of actual flow paths can be affected by small differences in topography which are not represented in such a resampled DEM. For example, both modelled paths show a third lobe deviating over the medial moraine from the right hand edge of the flow as it traveled through the lower Bannie icefall, but this phenomenon was not evident in either of the mapped deposits. This model artifact may result from a failure of the DEM to represent the 

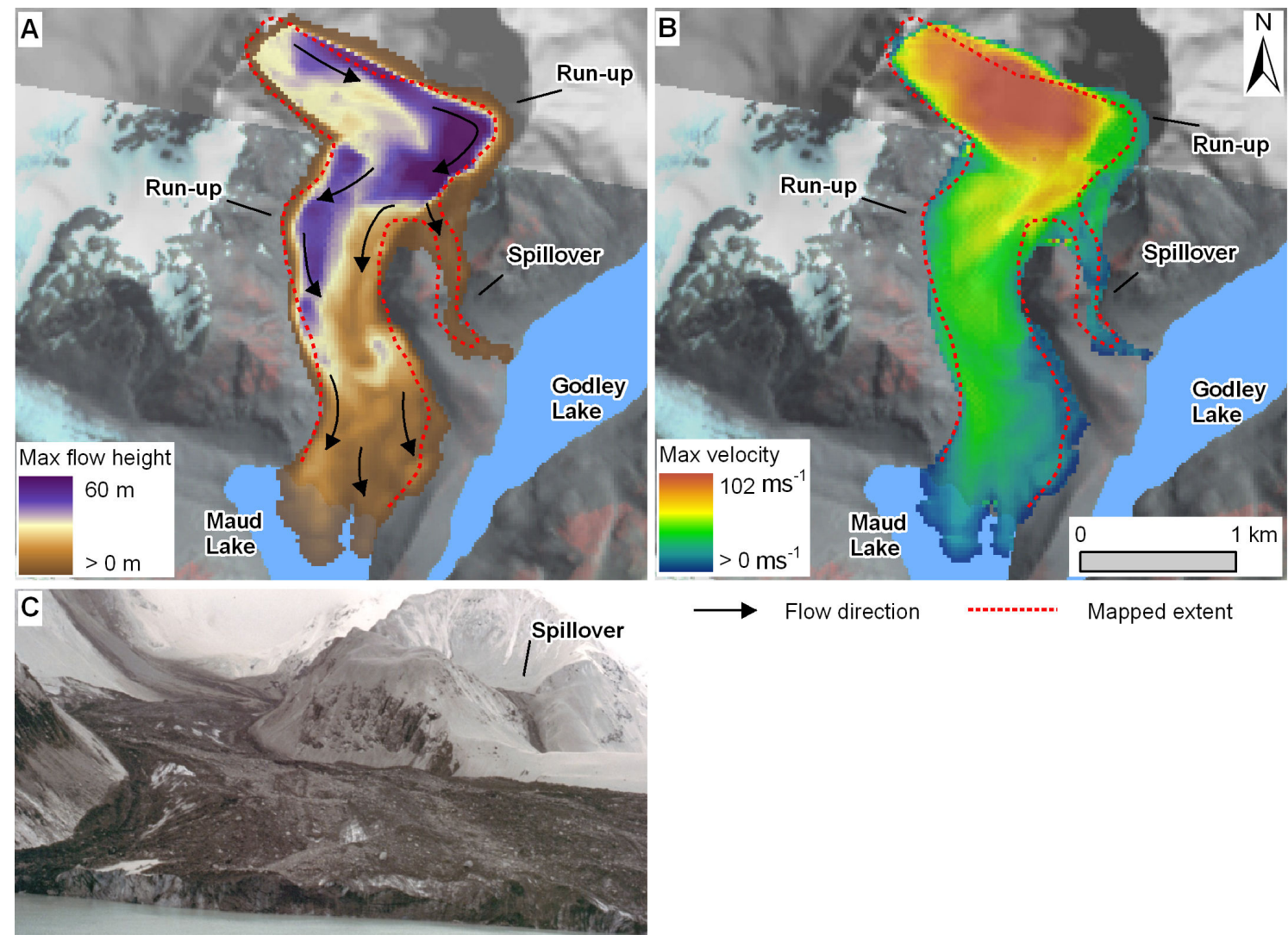

$\longrightarrow$ Flow direction

Mapped extent

Fig. 8. A RAMMS simulation of the 1992 Mount Fletcher rock avalanche showing maximum flow heights and B maximum velocity. Mapped avalanche extent is after McSaveney (2002). C View of the avalanche path observed from the glacial lake where partial deposition occurred, resulting in a displacement wave and flooding (photo: M. McSaveney, September 1992).
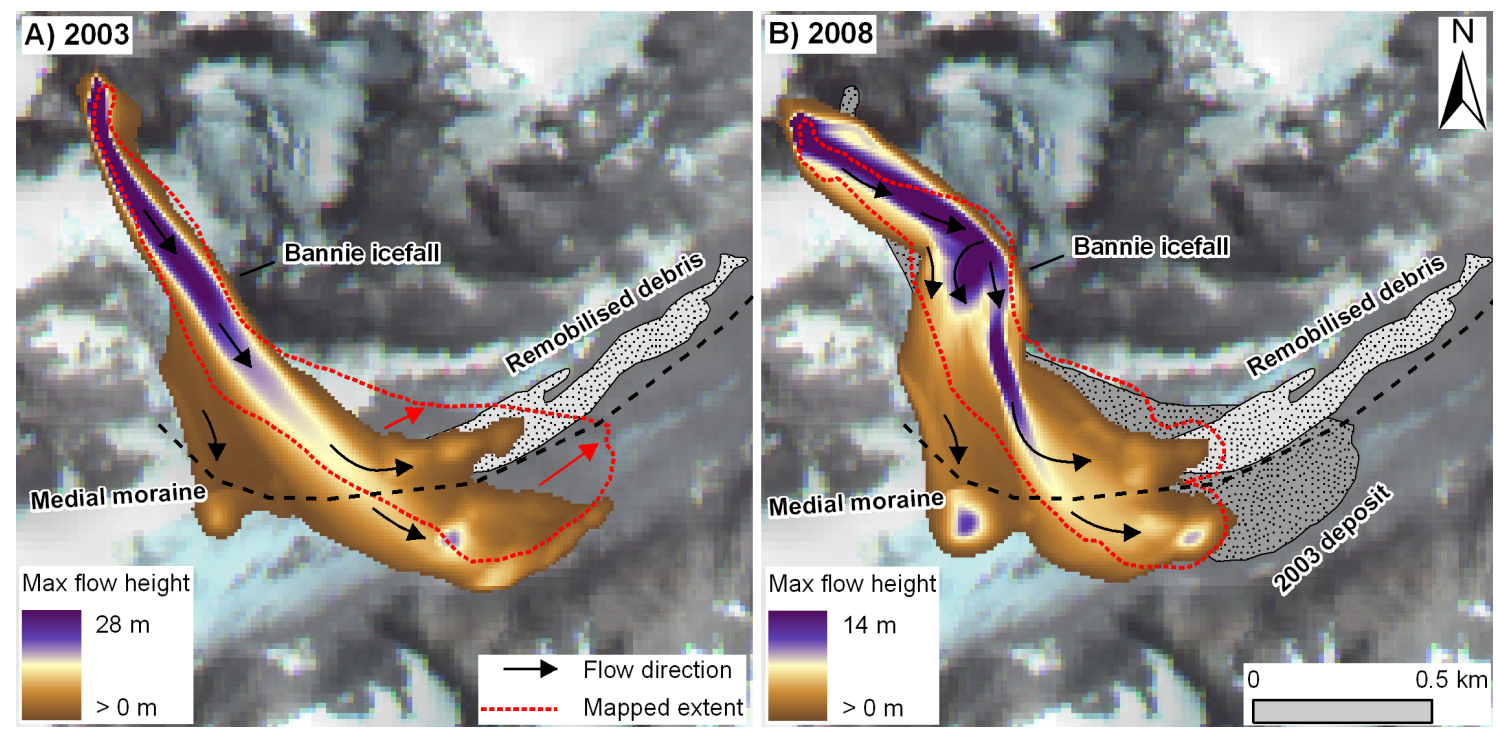

Fig. 9. RAMMS simulations of the A 2003, and B 2008 rock avalanches from Vampire Peak, Mueller Glacier, showing maximum flow heights. The 2003 avalanche and remobilised debris deposits are reconstructed from satellite imagery from January 2006 (Cox and Allen, 2009). As indicated by the red arrows, significant displacement of the avalanche deposit down the glacier is likely to have occurred between 2003 and 2006. 
micro-topography of the steep, chaotic icefall, the effects of different surface friction within the icefall that were not accounted for in the model run, or potential changes in the icefall topography that have occurred since the elevation data was captured in 1986.

Calibrating model simulations to reconstruct past events requires that the modelled flow paths fit geometrically in three dimensions as well as in time. The examples presented here form a small component of a calibration initiative for various rock/ice avalanche events from different glacial environments around the world, establishing an initial range of best fit frictional input parameters (Fig. 10) that may be used to simulate potential events where hazardous scenarios are recognized. This range of values encompass volumetric differences of two orders of magnitudes, unequal fractions of ice and water content and extremely variable topography. The development and expansion of this dataset over time, is expected to provide an indispensable basis for future model evaluation and scenario simulations with RAMMS.

\section{Discussion}

A first order GIS approach to glacial hazard modelling in the Mount Cook region allows non-specialist local authorities involved in regional management to quickly identify situations or locations where more detailed and comprehensive studies should be directed. With all GIS-based procedures, the reliability of the output is determined by the accuracy and characteristics of the input data used, model assumptions and limitations. Hazard sources used as input to the MSF model were derived on the basis of satellite terrain mapping and slope gradient thresholds, where the main limitations relate to the $25 \mathrm{~m}$ resolution of the DEM, and filtering procedures that operate across several pixel values further increasing the minimum size of recognized surface features (Allen et al., 2008b). In addition, the New Zealand $25 \mathrm{~m}$ DTM is developed from 1986 aerial photography, and significant topographic changes have occurred within the glacial landscape over recent decades, most evidently surrounding the larger valley glaciers, where ice surfaces have lowered up to $4 \mathrm{~m}$ per year (Blair, 1994). Elevation data computed from ASTER stereo imagery (Kääb et al., 2002) or the $90 \mathrm{~m}$ resolution shuttle radar topography mission (SRTM) (Schneider et al., 2008), can keep pace with changing environmental conditions, but provide reduced topographic detail and can have severe errors in steep terrain. For more advanced numerical models, such as RAMMS, topographic sensitivity becomes more pronounced, and therefore a lack of recent high resolution elevation data from the Southern Alps remains a limiting factor in representing complex flow dynamics.

The limitations of the MSF model are well documented by the developer (Huggel et al., 2003), and in the context of the Mount Cook region where empirical information is lacking, specifically relate to the inability of the model to give

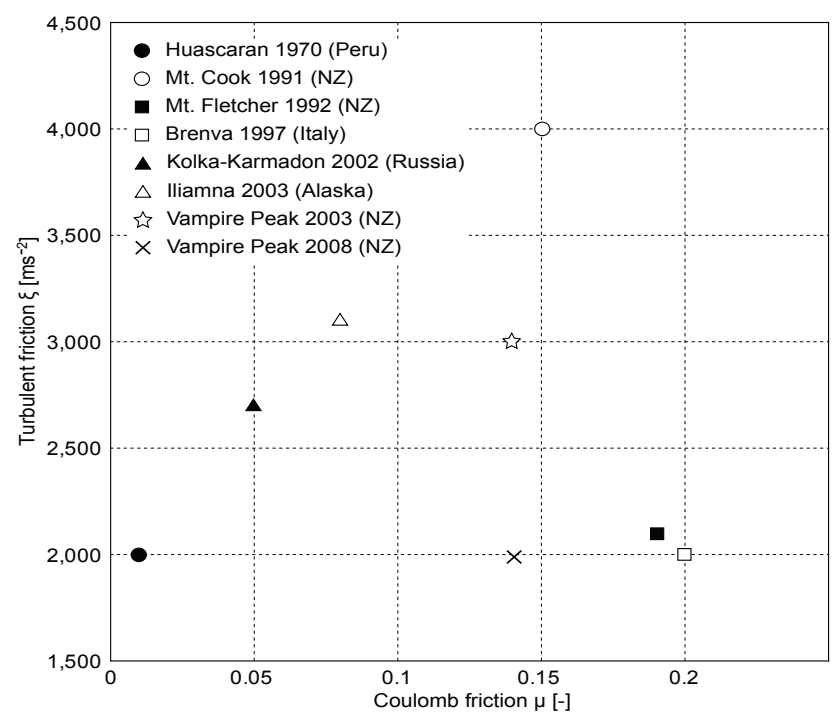

Fig. 10. Turbulent and coulomb friction best fit parameters established from simulating rock avalanche events in New Zealand (NZ) and other glacial regions using RAMMS. These values were iteratively found with the RAMMS program and should not be confused with the physical properties of the material as the internal and basal coefficients of friction. The Coulomb friction also can not directly be transformed to the widely used ratio of fall height to runout length $(\mathrm{H} / \mathrm{L})$. In a Voellmy model, the final runout distance also depends on the turbulent friction term (see Eqs. 1 and 2).

any direct information regarding potential flow magnitudes, erosion capabilities, and deposition volumes. At the next level of hazard investigation, this information may be calculated using combined empirical relationships and field observations (e.g., McKillop and Clague, 2007; Rickenmann, 1999). Preferably, calculations will be verified using physically based flood and mass movement models such as FLO2D (O'Brien et al., 1993) or DAN/DAN3D (Hungr, 1995), while the capabilities of RAMMS have been introduced for rock avalanche modeling in glacial environments. Greater input and computational requirements make these models best suited for local scale modelling of individual events or scenarios.

Empirical relationships represent a simplification of complex natural processes but remain useful for initial investigations and are most suitable for integration into GIS and remote sensing based approaches (Huggel et al., 2004). However, numerous climatic, topographic, geological, and glaciological factors differentiate the physical characteristics of processes occurring in one alpine region from another. Therefore, while often necessary, the extrapolation of well grounded empirical relationships must be treated cautiously and may not always be appropriate. Although not unique to New Zealand, the active tectonic setting and extreme precipitation gradient occurring across the Southern Alps has a 
paramount influence on geomorphic processes in the region, and related natural hazards. In particular, sediment yields may be several orders of magnitude higher than other regions (Fitzsimons and Veit, 2001) and locally enhanced by landslide activity and fault proximity (Hovius et al., 1997; Korup, 2004), while high intensity triggers (rain or earthquake) of mass movements may occur more frequently. As a consequence, there will be uncertainties associated with any attempt to quantify the longer term influence of climate and glacial change on event frequency and/or magnitude in this region. In addition, events initiating from glacial origins are only one component of mass movement processes in this mountainous region, where failure of hillslopes, river damming, debris and clear water floods not directly linked to glacial processes remain the most recognized threats to lowland populations (e.g., Davies and Scott, 1997; Korup, 2005b). Predicted climatic change, potentially bringing even greater rainfall in the west and dryer conditions in the east (Mullan et al., 2001), adds to the complexities that scientists must consider in relation to future mass movement and flood hazards in the Southern Alps.

A comparison of twentieth century glacial changes in the New Zealand and European Alps reveals comparable reductions in ice extent although New Zealand glaciers may be more sensitive to future climate warming (Hoelzle et al., 2007). However, lower equilibrium line altitudes and therefore restricted ablation zones in the Southern Alps means that lake development and moraine destabilization associated with glacial mass wastage has so far been limited to lower elevation zones east and west of the main divide. The steeper topographic expression of the Southern Alps inhibits lake development or significant moraine deposition at higher elevations. In contrast, glacial retreat in the European Alps has resulted in lake formation and unstable moraines in high elevation hanging valleys or cirque basins, often with populated valleys located below (e.g., Huggel et al., 2003). In addition, permafrost and its climate induced degradation is expected to cause further destabilization of unconsolidated moraine deposits and talus slopes, leading to increased debris flow potential in the European Alps (Harris, 2005). Results presented here suggest this is not a concern in the Mount Cook region, given that no potential debris flow source areas were identified at elevations above $2500 \mathrm{~m}$ where permafrost is expected on steeper slopes (Allen et al., 2008a). Permafrost degradation in the Southern Alps is therefore most relevant concerning a possible role in destabilization of high elevation bedrock slopes (e.g., Cox and Allen, 2009). This is alarming given the potential for impact induced floodwaves as many proglacial lakes in the region continue to expand. Furthermore, the expected probability of a large earthquake (>M7) striking the region during the next 50 years may be as high as $35 \%$ (Cox and Barrell, 2007), providing a trigger for future large magnitude movements of ice and rock, and possible floodwave initiation.

\section{Conclusions}

GIS based procedures were applied to gain first order knowledge of glacial flood, debris flow, and ice avalanche potential across the Mount Cook region of New Zealand's Southern Alps. Large volume lakes dammed by moraine and Quaternary gravels occur in proglacial areas below $1000 \mathrm{~m}$ where gentle slope gradients and well vegetated outlet channels indicate relatively stable conditions. Where smaller cirque lakes are dammed by steep morainic debris, debris flow scenarios were considered, but maximum probable runouts in these instances were well short of affecting any infrastructure. Potential debris flows were also modelled from glacial and recent paraglacial sediment accumulations, and in many instances runout paths intersected with human activity. However, examples illustrated near the Mount Cook village indicated a large discrepancy is possible between the static worstcase approach to runout modelling and maximum runout distances expected on the basis of catchment area available above the debris source. Direct impacts from potential high magnitude ice avalanches do not extend beyond walking tracks and some huts/shelters located in close proximity to steep ice, although numerous lakes are positioned within the runout paths from even smaller magnitude events, providing potential for displacement waves and flooding. The rapidly expanding Mueller Lake was illustrated as one example in close proximity to tourist and residential infrastructure, but longer term glacial recession and lake expansion will increase the potential for ice, debris or rock impacts into most lakes across the region. Physically based rock avalanche modelling with RAMMS provides a useful tool for recognizing detailed flow patterns, calculating potential flow magnitudes and velocities, and the application of this model for predictive purposes will benefit from further calibration studies. Further investigations are required at the local scale, assessing the likelihood of high magnitude flood, ice and debris hazards, and providing a comprehensive assessment of possible climate change impacts. Given an unstable geological setting and high potential for both seismic and rainfall triggered slope failures, a broader approach considering topographic, geological and glacial factors relating to bedrock failure susceptibility is encouraged. Uncertainty related to climate change and its influence on remote glacial regions should be met with robust methods for early recognition and monitoring of potential impacts.

Acknowledgements. This project is funded by a University of Canterbury doctoral scholarship. Quickbird imagery was sponsored by Digitial Globe ${ }^{T M}$. RAMMS was kindly made available by the WSL Institute for Snow and Avalanche Research, SLF, Davos, Switzerland and we are greatly indebted to the support of Perry Bartelt, Marc Christen and Julia Kowalski. Christian Huggel is gratefully acknowledged for allowing access to the MSF modelling code and for providing a comprehensive review of the initial manuscript. Data provided by 
the Department of Conservation is appreciated. We are most thankful for the constructive suggestions provided by two anonymous reviewers.

Edited by: J. M. Vilaplana

Reviewed by: two anonymous referees

\section{References}

Alean, J.: Ice avalanches: some empirical information about their formation and reach, J. Glaciol., 31, 324-333, 1985.

Allen, S., Owens, I., and Huggel, C.: A first estimate of mountain permafrost distribution in the Mount Cook region of New Zealand's Southern Alps, in: Ninth International Conference on Permafrost, edited by: Kane, D. L. and Hinkel, K. M., Institute of Northern Engineering, University of Alaska, Fairbanks, 3742, 2008a.

Allen, S., Owens, I., and Sirguey, P.: Satellite remote sensing procedures for glacial terrain analyses and hazard assessment in the Aoraki Mount Cook region, New Zealand, New Zeal. J. Geol. Geop., 51, 73-87, 2008b.

Barringer, J. R. F., McNeill, S. J., and Pairman, D.: Progress on assessing the accuracy of a high-resolution digital elevation model for New Zealand, 5th International Symposium on Spatial Accuracy Assessment in Natural Resources and Environmental Sciences, Melbourne, Australia, 10-12 July 2002,

Bartelt, P., Salm, B., and Gruber, U.: Calculating densesnow avalanche runout using a Voellmy-fluid model with active/passive longitudinal straining, J. Glaciol., 45, 242-254, 1999.

Blair Jr., R. W.: Moraine and valley wall collapse due to rapid deglaciation in Mount Cook National Park, New Zealand, Mt. Res. Dev., 14, 347-358, 1994.

Carey, M.: Living and dying with glaciers: people's historical vulnerability to avalanches and outburst floods in Peru, Global Planet. Change, 47, 122-134, 2005.

Chiarle, M., Iannotti, S., Mortara, G., and Deline, P.: Recent debris flow occurrences associated with glaciers in the Alps, Global Planet. Change, 56, 123-136, 2007.

Chinn, T. J. H.: New Zealand glacier responses to climate change in the past century, New Zeal. J. Geol. Geop., 39, 415-428, 1996.

Christen, M., Bartelt, P., Kowalski, J., and Stoffel, L.: Calculation of dense snow avalanches in three-dimensional terrain with the numerical simulation program RAMMS, Proceedings of the International Snow Science Workshop, Whistler, BC, Canada, 709-716, 2008.

Clague, J. J. and Evans, S. G.: Formation and failure of natural dams in the Canadian Cordillera, Geological Survey of Canada Bulletin 464, 35 pp., 1994.

Clague, J. J. and Evans, S. G.: A review of catastrophic drainage of moraine-dammed lakes in British Columbia, Quaternary Sci. Rev., 19, 1763-1783, 2000.

Cox, S. and Barrell, D. J. A. (compilers): Geology of the Aoraki Area, New Zealand, Institute of Geological \& Nuclear Sciences 1:250000 geological map 15, GNS Science, Lower Hutt, New Zealand, 1 sheet+71 pp., 2007.

Cox, S. C. and Allen, S. K.: Vampire rock avalanches of January 2008 and 2003, Southern Alps, New Zealand, Landslides, doi:10.1007/s10346-009-0149-4, in press, 2009.

Davies, T. R. and Scott, B. K.: Dambreak flood hazard from the Callery River, Westland, New Zealand, J. Hydrol. (New Zealand), 36, 1-13, 1997.

Davies, T. R., Smart, C. C., and Turnbull, J. M.: Water and sediment outbursts from advanced Franz Josef Glacier, New Zealand, Earth Surface Processes and Landforms, 28, 1081-1096, 2003.

Ding, Y., and Liu, J.: Glacial lake outburst flood disasters in China, Ann. Glaciol., 16, 180-184, 1992.

Dunning, J. S.: Form and process of alpine talus, Arthurs Pass, Southern Alps, New Zealand, unpublished Ph.D. thesis, Department of Geography, Univeristy of Canterbury, Christchurch, 133 pp., 1996.

Evans, S. G. and Clague, J. J.: Recent climatic change and catastrophic geomorphic processes in mountain environments, Geomorphology, 10, 107-128, 1994.

Fitzsimons, S. J. and Veit, H.: Geology and geomorphology of the European Alps and the Southern Alps of New Zealand, Mountain Research and Development, 21, 340-349, 2001.

Goodsell, B., Anderson, B., Lawson, W. J., and Owens, I. F.: Outburst flooding at Franz Josef Glacier, South Westland, New Zealand, New Zeal. J. Geol. Geop., 48, 95-104, 2005.

Haeberli, W.: Frequency and characteristics of glacier floods in the Swiss Alps, Ann. Glaciol., 4, 85-90, 1983.

Haeberli, W., Kääb, A., Paul, F., Chiarle, M., Mortara, G., Mazza, A., Deline, P., and Richardson, S.: A surge-type movement at Ghiacciaio del Belvedere and a developing slope instability in the east face of Monte Rosa, Macugnaga, Italian Alps, Norwegian Journal of Geography, 56, 104-111, 2002.

Hancox, G. T., McSaveney, M. J., Manville, V. R., and Davies, T. R.: The October 1999 Mt Adams rock avalanche and subsequent landslide dam-break flood and effects in Poerua River, Westland, New Zealand, New Zeal. J. Geol. Geop., 48, 683-705, 2005.

Harris, C.: Climate Change, Mountain Permafrost Degradation and Geotechnical Hazard, in: Global Change and Mountain Regions, An Overview of Current Knowledge, edited by: Huber, U. M., Bugmann, H. K. M., and Reasoner, M. A., Springer, Dordrecht, 215-224, 2005.

Henderson, R. D. and Thompson, S. M.: Extreme Rainfalls in the Southern Alps of New Zealand, J. Hydrol. (New Zealand), 38, 309-330, 1999.

Hewitt, K.: Natural dams and outburst floods in the Karakorum Himalaya., IAHS Publication, 138, 259-269, 1982.

Hochstein, M. P., Claridge, D., Henrys, S. A., Pyne, A., Nobes, D., and Leary, S. F.: Downwasting of the Tasman Glacier, South Island, New Zealand: changes in the terminus region between 1971 and 1993., New Zeal. J. Geol. Geop., 38, 1-16, 1995.

Hoelzle, M., Chinn, T., Stumm, D., Paul, F., Zemp, M., and Haeberli, W.: The application of glacier inventory data for estimating past climate change effects on mountain glaciers: A comparison between the European Alps and the Southern Alps of New Zealand, Global Planet. Change, 56, 69-82, 2007.

Hovius, N., Stark, C. P., and Allen, P. A.: Sediment flux from a mountain belt derived from landslide mapping, Geology, 25, 231-234, 1997.

Huggel, C., Kääb, A., Haeberli, W., Teysseire, P., and Paul, F.: Remote sensing based assessment of hazards from glacier lake outbursts: a case study in the Swiss Alps, Can. Geotech. J., 39, 316-330, 2002. 
Huggel, C., Kääb, A., Haeberli, W., and Krummenacher, B.: Regional-scale GIS-models for assessment of hazards from glacier lake outbursts: evaluation and application in the Swiss Alps, Nat. Hazards Earth Syst. Sci., 3, 647-662, 2003, http://www.nat-hazards-earth-syst-sci.net/3/647/2003/.

Huggel, C., Kääb, A., and Salzmann, N.: GIS-based modeling of glacial hazards and their interactions using Landsat-TM and IKONOS imagery, Norwegian Journal of Geography, 58, 61-73, 2004.

Huggel, C., Zgraggen-Oswald, S., Haeberli, W., Kääb, A., Polkvoj, A., Galushkin, I., and Evans, S. G.: The 2002 rock/ice avalanche at Kolka/Karmadon, Russian Caucasus: assessment of extraordinary avalanche formation and mobility, and application of QuickBird satellite imagery, Nat. Hazards Earth Syst. Sci., 5, 173-187, 2005,

http://www.nat-hazards-earth-syst-sci.net/5/173/2005/.

Hungr, O., Morgan, G. C., and Kellerhals, P.: Quantitative analysis of debris hazards for design of remedial measures, Can. Geotech. J., 21, 663-677, 1984.

Hungr, O.: A model for the runout analysis of rapid flow slides, debris flows, and avalanches, Can. Geotech. J., 32, 610-623, 1995.

Hungr, O., McDougall, S., and Bovis, M.: Entrainment of material by debris flows, in: Debris-flow hazards and related phenomena, edited by: Jakob, M., and Hungr, O., Springer - Praxis, Berlin Heidelberg, 135-155, 2005.

Irwin, D., MacQueen, W., and Owens, I.: Avalanche Accidents in Aotearoa New Zealand, N.Z. Mountain Safety Council, Wellington, 153 pp., 2002.

Iseli, J. G.: Ice avalanche activity in Mount Cook National Park, unpublished M.Sc. thesis, Department of Geography, University of Canterbury, Christchurch, 151 pp., 1991.

Kääb, A., Huggel, C., Paul, F., Wessels, R., Raup, B., Kieffer, H., and Kargel, J.: Glacier monitoring from ASTER imagery: accuracy and applications, Proceedings of EARSel-LISSIGWorkshop Observing our Cryosphere from Space, Bern, 43-53, 2002.

Kääb, A., Reynolds, J. M., and Haeberli, W.: Glacier and Permafrost Hazards in High Mountains, in: Global Change and Mountain Regions. An Overview of Current Knowledge, edited by: Huber, U. M., Bugmann, H. K. M., and Reasoner, M. A., Springer, Dordrecht, 225-234, 2005.

Kern, M., Tiefenbacher, F., and McElaine, J.: The rheology of snow in large chute flows, Cold Reg. Sci. Technol., 39, 181-192, 2004.

Koons, P. O.: The two-sided orogen: Collision and erosion from the sandbox to the Southern Alps, New Zealand, Geology, 18, 679-682, 1990.

Korup, O.: Geomorphic implications of fault zone weakening: slope instability along the Alpine Fault, South Westland to Fiordland, New Zeal. J. Geol. Geop., 47, 257-267, 2004.

Korup, O.: Distribution of landslides in southwest New Zealand, Landslides, 2, 43-45, 2005a.

Korup, O.: Geomorphic hazard assessment of landslide dams in South Westland, New Zealand: Fundamental problems and approaches, Geomorphology, 66, 167-188, 2005b.

Maizels, J. and Russel, A. J.: Quaternary perspectives on Jokulhlaup prediction, Quaternary Proceeedings, 2, 133-152, 1992.

McKillop, R. J. and Clague, J. J.: A procedure for making objective preliminary assessments of outburst flood hazard from morainedammed lakes in southwestern British Colombia, Nat. Hazards,
41, 131-157, 2007.

McSaveney, M. J.: Recent rockfalls and rock avalanches in Mount Cook National Park, New Zealand, Geology Society of America, Reviews in Engineering Geology, XV, 35-69, 2002.

McSaveney, M. J. and Davies, T. R.: Engineering for debris flows in New Zealand, in: Debris-flow hazards and related phenomena, edited by: Jakob, M. and Hungr, O., Praxis Publishing, Chichester, 635-658, 2005.

Mullan, A. B., Wratt, D. S., and Renwick, J. A.: Transient model scenarios of climate changes for New Zealand, Weather and Climate, 21, 3-34, 2001.

O'Brien, J. S., Julien, P. Y., and Fullertone, W. T.: Two-dimensional water flood and mudflow simulation, J. Hydraul. Eng.-ASCE, 119, 244-261, 1993.

O'Connor, J. E., Hardison, J. H., and Costa, J. E.: Debris flows from failures of Neoglacial-Age moraine dams in the Three Sisters and Mount Jefferson wilderness areas, Oregon, US Geological Survey Professional Paper, 1606, 93 pp., 2001.

Paterson, B. R.: Slope instability along state highway 73 through Arthur's Pass, South Island, New Zealand, New Zeal. J. Geol. Geop., 39, 339-351, 1996.

Quincey, D. J., Richardson, S. D., Luckman, A., Lucas, R. M., Reynolds, J. M., Hambrey, M. J., and Glasser, N. F.: Early recognition of glacial lake hazards in the Himalaya using remote sensing datasets, Global Planet. Change, 56, 137-152, 2007.

Reynolds, J. M.: The identification and mitigation of glacier-related hazards: examples from the Cordillera Blanca, Peru, in: Geohazards natural and man-made, edited by: McCall, G. J. H., Laming, D. J. C., and Scott, S. C., Chapman and Hall, London, 143-157, 1992.

Richardson, S. D. and Reynolds, J. M.: An overview of glacial hazards in the Himalayas, Quatern. Int., 65/66, 31-47, 2000.

Rickenmann, D. and Zimmermann, M.: The 1987 debris flows in Switzerland: documentation and analysis, Geomorphology, 8, 175-189, 1993.

Rickenmann, D.: Empirical relationships for debris flows, Nat. Hazards, 19, 47-77, 1999.

Rickenmann, D.: Runout prediction methods, in: Debris-flow hazards and related phenomena, edited by: Jakob, M. and Hungr, O., Springer - Praxis, Berlin Heidelberg, 305-321, 2005.

Röhl, K.: Behaviour of lake-terminating glacier margins, unpublished Ph.D. thesis, Department of Geography, University of Otago, Dunedin, 390 pp., 2005.

Salzmann, N., Kaab, A., Huggel, C., Allgower, B., and Haeberli, W.: Assessment of the hazard potential of ice avalanches using remote sensing and GIS-modelling, Norwegian Journal of Geography, 58, 74-84, 2004.

Schneider, D., Delgado Granados, H., Huggel, C., and Kääb, A.: Assessing lahars from ice-capped volcanoes using ASTER satellite data, the SRTM DTM and two different flow models: case study on Iztacchuatl (Central Mexico), Nat. Hazards Earth Syst. Sci., 8, 559-571, 2008, http://www.nat-hazards-earth-syst-sci.net/8/559/2008/.

Skermer, N. A., Rawlings, G. E., and Hurley, A. J.: Debris flow defences at Aoraki Mount Cook Village, New Zealand, Q. J. Eng. Geol. Hydroge., 35, 19-24, 2002.

Sovilla, B., Burlando, P., and Bartelt, P.: Field experiments and numerical modeling of mass entrainment in snow avalanches, $\mathrm{J}$. Geophys. Res., 111, 1-16, 2006. 
Takahashi, T.: Debris Flow, A. A. Balkema, Rotterdam, 165 pp., 1991.

Warren, C. R. and Kirkbride, M.: Temperature and bathymetry of ice-contact lakes in Mount Cook National Park, New Zealand, New Zeal. J. Geol. Geop., 41, 133-143, 1998.

Wegmann, M., Funk, M., Flotron, A., and Keusen, H.: Movement studies to forecast the time of breaking off of ice and rock masses, in: Early Warning Systems for Natural Disasters Reduction, edited by: Zschau, J. and Küppers, A., Springer Verlag, Berlin, 565-568, 2003.

Wells, A., Duncan, R. P., Stewart, G. H., and Yetton, M. D.: Prehistoric dates of the most recent Alpine Fault earthquakes, New Zealand, Geology, 27, 995-998, 1999.
Whitehouse, I. E.: Erosion on Sebastopol, Mt Cook, New Zealand, in the last 85 years, New Zealand Geographer, 38, 77-80, 1982.

Whitehouse, I. E. and Griffiths, G. A.: Frequency and hazard of large rock avalanches in the central Southern Alps, New Zealand, Geology, 11, 331-334, 1983.

Whitehouse, I. E. and McSaveney, M. J.: Diachronous talus surfaces in the Southern Alps, New Zealand, and their implications to talus accumulation, Arctic Alpine Res., 15, 53-64, 1983.

Whitehouse, I. E.: Geomorphology of the central Southern Alps, New Zealand, Z. Geomorphol., 69, 105-116, 1988.

Zimmermann, M. and Haeberli, W.: Climatic change and debris flow activity in high mountain areas: a case study in the Swiss Alps, Catena Supplement, 22, 49-72, 1992. 